\title{
Helicobacter pylori associated with breastfeeding, nutritional status and recurrent abdominal pain in healthy Nigerian children
}

\author{
Idowu O Senbanjo ${ }^{1}$, Kazeem A Oshikoya ${ }^{2}$, Olisamedua F Njokanma ${ }^{1}$ \\ ${ }^{1}$ Department of Paediatrics and Child Health, Lagos State University College of Medicine, Ikeja, Lagos State, \\ Nigeria \\ ${ }^{2}$ Pharmacology Department, Lagos State University College of Medicine, Ikeja, Lagos State, Nigeria
}

\begin{abstract}
Introduction: There is limited knowledge about the associations of Helicobacter pylori (H. pylori) infections in developing countries. This study aimed to determine the current prevalence and associations of $H$. pylori infection with breastfeeding practices, nutritional status, and recurrent abdominal pain (RAP) in a group of apparently healthy children and adolescents in Lagos, Nigeria.

Methodology: This was a prospective hospital-based study conducted at the Lagos State University Teaching Hospital that involved 118 children who came to the hospital for routine pediatric care. Seroprevalence status of the children was determined by measuring immunoglobulin $\mathrm{G}$ antibodies against $H$. pylori using enzyme-linked immunosorbent assay (ELISA).

Results: Seventy-five (63.6\%) children were seropositive for $H$. pylori. The prevalence of $H$. pylori infection increased significantly from $40.4 \%$ in children less than five years of age to $85.1 \%$ at six to ten years of age $\left(\chi^{2}=20.9, \mathrm{p}<0.001\right)$. H. pylori infection was associated with low social class $(\mathrm{OR}=3.24 ; 95 \% \mathrm{CI}=1.20-8.23, \mathrm{p}=0.016)$ and with $\mathrm{RAP}(\mathrm{OR}=3.47 ; 95 \% \mathrm{CI}=1.55-7.79, \mathrm{p}=0.002)$, but no association was observed with exclusive breastfeeding, duration of breastfeeding, and under-nutrition.

Conclusions: The prevalence of $H$. pylori infection is high, particularly among children from low socioeconomic backgrounds in Lagos, Nigeria. It is associated with RAP. The effect of this infection on children's health requires further studies.
\end{abstract}

Key words: Helicobacter pylori; prevalence; breastfeeding practices; malnutrition; recurrent abdominal pain

J Infect Dev Ctries 2014; 8(4):448-453. doi:10.3855/jidc.3196

(Received 30 November 2012 - Accepted 19 August 2013)

Copyright $(2014$ Senbanjo et al. This is an open-access article distributed under the Creative Commons Attribution License, which permits unrestricted use, distribution, and reproduction in any medium, provided the original work is properly cited.

\section{Introduction}

Helicobacter pylori is a Gram-negative, microaerophilic, spiral-shaped bacterium that was first identified by Barry Marshall and Robin Waren in 1982 $[1,2]$. This microorganism is ubiquitous and infects over half of the global population [1,2]. The rate of infection is higher in developing than in developed countries [1,2]. The organism was initially isolated from a human gastric biopsy and is considered an etiological factor of active and chronic gastritis, peptic ulcer disease, and gastric adenocarcinoma [1-3]. The list of disease entities with which the organism is causally related has increased to include recurrent abdominal pain, gastric mucosa-associated lymphoid tissue lymphoma, gastro-esophageal reflux disease, obesity, growth retardation, and, more recently, extragastric diseases such as coronary heart disease, normal tension glaucoma, and idiopathic thrombocytopenic purpura $[3,4]$. In developing countries, there is evidence that $H$. pylori can cause suppression of the gastric acid barrier, allowing enteropathogens ingested from contaminated weaning foods to gain access to the small intestine. This predisposes to childhood diarrhea, malabsorption of essential nutrients such as vitamins $\mathrm{C}$ and B12, and growth failure in childhood $[5,6]$.

$H$. pylori infection is acquired early in life and builds up; once established, persists into adulthood [2]. Despite several epidemiological studies, the route of transmission of the infection is not entirely clear [2,3]. Evidence suggests that human-to-human contact may play a significant role in its transmission [7]. This mode of transmission may be mediated by breastfeeding, overcrowding, and poor hygienic practices. The finding of $H$. pylori in saliva, dental plaque, oral cavity, tonsillar tissue, oesophagus, and treated drinking water supports the possibility of human-to-human transmission occurring either through oral-oral and feco-oral routes [7].

Most studies focusing on $H$. pylori infection in Nigeria focused on adults. Only a few studies on children are available $[8,9]$. Unfortunately, none of the 
pediatric studies examined the relationship between $H$. pylori infection, feeding practices, and child nutritional status. Similarly, there has been no report on the association between $H$. pylori infection and recurrent abdominal pain among healthy children in Nigeria. Therefore, this study aimed to determine the current prevalence and determinants of $H$. pylori infection among healthy children in Lagos, Nigeria. It also aimed to determine if the infection was associated with recurrent abdominal pains, breastfeeding, and the nutritional status of the children.

\section{Methodology}

Setting

This study was conducted prospectively at the general outpatient clinic of the Department of Paediatrics and Child Health, Lagos State University Teaching Hospital (LASUTH), Ikeja, Lagos. The hospital is a tertiary health facility owned by the Lagos State Government. It has about 200 bed spaces for children and is located in the Ikeja Local Government Area. Health care is provided free of charge to children and the elderly. The hospital serves the inhabitants of Lagos State and the neighboring Ogun State.

The general pediatric outpatient clinic is open every weekday and is closed on Saturdays, Sundays, and public holidays. An average of 150 patients are seen daily, about 10 of whom are on routine follow-up visits.

\section{Selection of subjects}

The subjects were children who had recovered from acute illnesses such as malaria, upper respiratory tract infection (URTI), vernal conjunctivitis, otitis media, and urinary tract infection (UTI) and were on follow-up visits to the general pediatric outpatient clinic. They were recruited between March 5 and March 28, 2009. Subjects were included in the study if the accompanying parents or guardians gave informed consent; additionally, children older than six years of age gave their assent. Each parent/guardian was interviewed in a private room by one of the researchers in accordance with a proforma specifically designed for the study. Information about demographics, breastfeeding practices, socioeconomic and environmental characteristics of the family was obtained. Families were classified into a socio-economic class according to the method of Ogunlesi et al. [10].

History of recurrent abdominal pain was specifically sought from the parent/guardian.
Clinically significant recurrent abdominal pain was defined according to Ukarapol et al. [11] as a minimum of three episodes of upper abdominal pain experienced within the last three consecutive months of the clinic appointment that were severe enough to affect the normal activities of the child and required medical attention. Children who had received proton pump inhibitors, H2-receptor antagonists, amoxicillin, metronidazole, or clarithromycin within two weeks prior to the study were excluded. A complete history that focused on dyspeptic symptoms was done and a physical examination was performed by a pediatric gastroenterologist (IOS). Peptic-like or dysmotilitylike dyspepsia was diagnosed according to the criteria of Ukarapol et al. [11].

\section{Ethical approval}

Ethical clearance was obtained from the hospital's research/ethics committee. The ethical approval file number is LREC/10/06/297.

\section{Serological test for Helicobacter pylori}

Approximately $1.5 \mathrm{~mL}$ of venous blood was aseptically collected from each patient. The sample was centrifuged at $2000 \mathrm{~g}$ for two minutes, and the serum was separated and frozen until assayed. Determination of immunoglobulin $\mathrm{G}$ to $H$. pylori was done by enzyme-linked immunosorbent assay. This involved using a test kit produced by Dia.Pro Diagnostic (Bioprobes, Milano, Italy). The kit was over $98 \%$ specific and sensitive.

\section{Data analysis and presentation}

Data was analyzed by descriptive and inferential statistics using SPSS for Windows software version 11. Means and standard deviations (SD) were calculated for continuous variables while proportions were calculated for categorical variables. Categorical variables were compared using the Pearson chisquared $\left(\chi^{2}\right)$ test. Odds ratios with $95 \%$ confidence intervals $(95 \% \mathrm{CI})$ were calculated to measure the degree of relationship between risk factors for $H$. pylori infection and $H$. pylori seropositivity. Probability ( $p$ value) of less than 0.05 or $95 \%$ CI not embracing unity was accepted as statistically significant.

\section{Results}

The sample population consisted of 118 children. The mean age was $7.01 \pm 3.58$ years, and $58(49.2 \%)$ were females. The social class distribution showed that $20(16.9 \%)$ and $98(83.1 \%)$ belonged to upper and 
lower socio-economic classes, respectively. Seventyfive $(63.6 \%)$ children were seropositive for $H$. pylori infection.

Table 1 shows the relationship between H. pylori and socio-demographic factors of the study group. Twenty-one (40.4\%) children up to five years of age were infected with $H$. pylori, and the prevalence increased significantly $\left(\chi^{2}=20.9, \mathrm{p}<0.001\right)$ with age to $85.1 \%$ at $6-10$ years. Subsequently, the rate decreased significantly to $73.7 \%$ at $11-15$ years $\left(\chi^{2}=\right.$ $6.17, \mathrm{p}=0.012)$. The only identified risk factor for $H$. pylori infection was low social class $(\mathrm{OR}=3.24 ; 95 \%$ $\mathrm{CI}=1.20-8.23, \mathrm{p}=0.016)$. However, $H$ pylori infection was not significantly associated with other household factors.

Table 2 shows the associations of $H$. pylori with feeding practices, nutritional status, recurrent abdominal pain. There was no significant association with exclusive breastfeeding for six months $\left(\chi^{2}=\right.$ $0.683, \mathrm{p}=0.409)$, duration of breastfeeding $\left(\chi^{2}=\right.$ $2.699, \mathrm{p}=0.100)$, formula feeding $\left(\chi^{2}=1.13, \mathrm{p}\right.$ $=0.289)$, thinness $\left(\chi^{2}=0.072, \mathrm{p}=0.789\right)$, and stunting $\left(\chi^{2}=0.234, p=0.629\right)$.

There was a threefold higher chance of recurrent abdominal pain in children infected with $H$. pylori $(\mathrm{OR}=3.47,95 \% \mathrm{CI}=1.55-7.79, \mathrm{p}=0.002)$. Of the 118 subjects studied, $30(25.4 \%)$ had epigastric tenderness and of those, $22(40.0 \%)$ had a history of RAP. Thus, abdominal tenderness was more often encountered among children with $\operatorname{RAP}\left(\chi^{2}=11.7, \mathrm{p}=\right.$ $0.003)$.

\section{Discussion}

The overall prevalence of $H$. pylori infection in our study of apparently healthy children in Lagos, Nigeria was $63.6 \%$, which is similar to the $69 \%$ reported for a pediatric age group from the northern part of Nigeria [8], but higher than the $14 \%$ reported from southern Nigeria [9] and the $11 \%$ among children who presented with dyspepsia in a tertiary health facility in Abakaliki in southeastern Nigeria [12]. The reason for this difference in prevalence within the Nigerian population is largely unknown, but could be due to the difference in socio-cultural factors, which affect carriage of the organism. For instance, the people from southern and southeastern parts of Nigeria are known to freely consume many vegetables and traditional herbal medicines compared to those from southwestern and northern parts of Nigeria [13]. Many of these plants include Allium vegetables, Morinda lucida vegetables, Ocimum gratissimum, Carica papaya, and Phyllantus amarus, which are known to have antibiotic properties against $H$. pylori. $[14,15]$. The inhibitory activities of these plants on $H$. pylori proliferation may have affected the rates of infection in different geographic zones in Nigeria.

Comparing our data with those from other developing countries, the prevalence of $H$. pylori infection in our study was as high as the rates previously reported among pediatric age groups in the Republic of Benin [16], Egypt [17], India [18], and Pakistan [19]. In contrast, a significantly lower prevalence of $7 \%$ to $24.8 \%$ has been reported among pediatric age group in New Zealand [20], Germany [21], and the United States [22]. Low socio-economic status and poor environmental and living conditions have been named as possible reasons for the differences in the prevalence of $H$. pylori infection among children in the developing and developed countries $[16,17]$. In the present study, a significantly high risk of $H$. pylori infection was observed in the low socio-economic class, similar to the findings in previous studies $[1,8,11]$. It is conceivable that the living conditions and sanitary habits of children from families with low incomes may likely be poor, thus increasing their susceptibility to $H$. pylori infection; however, this may not be true in all cases, as an alternative source of $H$. pylori infection that is independent of social class may exist.

One of the advantages of breastfeeding over formula feeding is that breast milk contains biological compounds of anti-infective nature. However, the results of studies on the protective effect of breastfeeding against acquisition of $H$. pylori are conflicting. Ertem et al. [23] reported in their study that breastfeeding has protective effects against $H$. pylori infection, which was in contrast to the lack of protective effects reported by Rodriques et al. [24]. In a prospective study in Gambia, Thomas et al. [25] found a high titre of specific $\operatorname{IgA}$ antibodies against $H$. pylori in mothers' breast milk. These anti-H. pylori antibodies have been shown in vitro to inhibit adherence of the organism to gastric cells. On the contrary, Rothenbacher et al. [26] reported an increase in the rate of $H$. pylori infection with breastfeeding, especially in children breastfed longer than six months. In our study, we did not find any significant protective effect of breastfeeding against $H$. pylori infection, but the decrease in the prevalence of $H$. pylori infection with increase in duration of breastfeeding up to 17 months would suggest a dose response protective effect of $\operatorname{IgA}$ antibodies in breast milk. 
Table 1. Influence of socio-demographic factors on seropositivity for Helicobacter pylori infection

\begin{tabular}{|c|c|c|c|c|}
\hline & H. pylori-positive & H. pylori-negative & OR & $95 \% \mathrm{CI}$ \\
\hline \multicolumn{5}{|l|}{ Age (years) } \\
\hline$\leq 5$ & $21(40.4)$ & $31(59.6)$ & 1 & \\
\hline $6-10$ & $40(85.1)$ & $7(14.9)$ & 8.44 & $3.18-22.4^{*}$ \\
\hline $11-15$ & $14(73.7)$ & $5(26.3)$ & 4.13 & $1.29-13.2 * *$ \\
\hline \multicolumn{5}{|l|}{ Gender } \\
\hline Male & $36(50.0)$ & $24(40.0)$ & 1 & \\
\hline Female & $39(67.2)$ & $19(32.8)$ & 1.12 & $0.85-1.47$ \\
\hline \multicolumn{5}{|l|}{ Mother's level of education } \\
\hline Postsecondary & $61(61.0)$ & $39(39.0)$ & 1 & \\
\hline At least secondary & $14(77.8)$ & $4(22.2)$ & 1.85 & $0.95-1.71$ \\
\hline \multicolumn{5}{|l|}{ Father's level of education } \\
\hline Postsecondary & $69(62.2)$ & $42(37.8)$ & 1 & \\
\hline At least secondary & $6(85.7)$ & $1(14.3)$ & 1.38 & $0.99-1.93$ \\
\hline \multicolumn{5}{|l|}{ Social class } \\
\hline Upper & $8(40.0)$ & $12(60.0)$ & 1 & \\
\hline Lower & $67(68.4)$ & $31(31.6)$ & 3.24 & $1.20-8.73^{*}$ \\
\hline \multicolumn{5}{|l|}{ Household size } \\
\hline$\leq 4$ & $66(65.5)$ & $35(34.7)$ & 1 & \\
\hline Greater than 4 & $9(52.9)$ & $8(47.1)$ & 1.23 & $0.77-1.98$ \\
\hline \multicolumn{5}{|l|}{ Water supply } \\
\hline Safe & $22(56.4)$ & $17(43.6)$ & 1 & \\
\hline Unsafe & $53(67.1)$ & $26(32.9)$ & 1.58 & $0.72-3.46$ \\
\hline \multicolumn{5}{|l|}{ Toilet facility } \\
\hline Water closet & $61(63.5)$ & $35(36.5)$ & 1 & \\
\hline Pit latrine & $14(63.6)$ & $8(36.4)$ & 1.00 & $0.71-1.42$ \\
\hline
\end{tabular}

Table 2. Association of $H$. Pylori infection with feeding practices, nutritional status and recurrent abdominal pain

\begin{tabular}{|c|c|c|c|c|}
\hline & H. Pylori-positive & H. Pylori-negative & OR & $95 \% \mathrm{CI}$ \\
\hline \multicolumn{5}{|c|}{ Exclusively breastfed for 6 months } \\
\hline No & $60(61.9)$ & $37(38.1)$ & 1 & \\
\hline Yes & $15(71.4)$ & $6(28.6)$ & 1.54 & $0.55-1.54$ \\
\hline \multicolumn{5}{|c|}{ Duration of breastfeeding } \\
\hline$<6$ months & $2(50.0)$ & $2(50.0)$ & 1 & \\
\hline 6-11 months & $8(36.4)$ & $14(63.6)$ & 1.75 & $0.21-14.9$ \\
\hline $12-17$ months & $18(32.7)$ & $37(67.3)$ & 2.03 & $0.20-20.8$ \\
\hline$\geq 18$ months & $15(40.5)$ & $22(59.5)$ & 1.45 & $0.14-15.3$ \\
\hline \multicolumn{5}{|c|}{ Infant formula feeding } \\
\hline No & $30(69.8)$ & $13(30.2$ & 1 & \\
\hline Yes & $45(60.0)$ & $30(40.0)$ & 0.65 & $0.29-1.44$ \\
\hline \multicolumn{5}{|c|}{ Height-for-age z-score } \\
\hline Not stunted & $72(63.2)$ & $42(11.4)$ & 1 & \\
\hline Stunted & $3(75.0)$ & $1(25.0)$ & 1.02 & 0.91-1.09 \\
\hline \multicolumn{5}{|c|}{ BMI-for-age z-score } \\
\hline Not thin & $65(63.1)$ & $38(36.9)$ & 1 & \\
\hline Thin & $10(66.7)$ & $3(33.3)$ & 1.02 & $0.89-1.17$ \\
\hline \multicolumn{5}{|c|}{ Recurrent abdominal pain } \\
\hline No & $32(50.8)$ & $31(49.2)$ & 1 & \\
\hline Yes & $43(78.2)$ & $12(21.8)$ & 3.47 & $1.55-7.79 *$ \\
\hline
\end{tabular}

Figures in parenthesis are percentages of the total in the respective row; ${ }^{*} \mathrm{p}<0.01$; OR $=$ odds ratio; $95 \% \mathrm{CI}=95 \%$ confidence interval 
Future community-based studies that involve a larger sample size may be necessary to ascertain this relationship.

Similarly, there have been conflicting results about the association of $H$. pylori infection with growth in children. While many researchers reported an association of $H$. pylori infection with growth delay $[5,6,17,27,28]$, a few did not find such an association [29-31]. Our study did not show a significant relationship with stunting and thinness of the children studied. It is worth noting that, even in those studies that reported a significant relationship between $H$. pylori infection and nutritional status, it may be difficult to ascribe the relationship to a direct effect of H. pylori on growth due to the presence of other confounders that may affect both $H$. pylori acquisition and nutritional status of the children.

The association between $H$. pylori infection and RAP continues to generate controversial reports. Studies from India [32], Sweden [33], and Canada [34] have shown no association between $H$. pylori and RAP. Similarly, many meta-analyses and reviews $[35,36]$ have shown that there is no association between $H$. pylori and RAP. However, in this study, we found that the prevalence of $H$. pylori infection among children with RAP was three-and-a-half times greater than those without RAP. Similar findings have been reported in Saudi Arabia [37] and the United States [38]. In sub-Saharan Africa, RAP is common in children and helminthiasis is the proven etiology, particularly in low socio-economic settings [39]. This has been responsible for the common practice of parents administering anthelmintics to their children following complaints of RAP. However, our findings suggest a possible additional role of $H$. pylori in RAP, although this will need to be confirmed by an interventional study in a larger population of children to ascertain the role of $H$. pylori in RAP.

A major limitation of this study is that it was based on subjects recruited from the hospital. Excluding subjects from the general pediatric population made it difficult to generalize our results. As in most other developing countries, it is very difficult in Nigeria to get subjects from the general pediatric population to give their consent or assent for blood sampling for research purposes. This limitation may have contributed to the dearth of community-based studies on $H$. pylori in Africa. Therefore, further research involving the urea breath test or the fecal antigen test, which may be relatively more acceptable to people in the community, may be desirable and useful in developing countries.
We concluded that the prevalence of $H$. pylori infection among apparently healthy children and adolescents in Lagos, Nigeria was high, particularly in the lower socio-economic class. There was no significant association between $H$. pylori infection and breastfeeding or the nutritional status of children. However, the prevalence of $H$. pylori infection was significantly high in children with RAP. Communitybased studies, as well as interventional studies, are required to ascertain the causal relationships between H. pylori infection and RAP identified in the present study.

\section{Acknowledgements}

We thank all the children and their mothers who gave their time to complete our questionnaire. We also thank all the house officers and medical officers who assisted in collecting this information.

\section{References}

1. Bardhan PK (1997) Epidemiological features of Helicobacter pylori infection in developing countries. Clin Infect Dis 25: 973-978.

2. Sycora J, Rowland M (2011) Helicobacter pylori in Pediatrics. Helicobacter 16 Suppl 1: 59-64.

3. Suzuki H, Franceschi F, Nishizawa T, Gasbarrini A (2011) Extragastric manifestations of Helicobacter pylori infection. Helicobacter 16 Suppl 1: 65-69.

4. Dale A, Thomas JE, Darboe MK, Coward WA, Harding M, Weaver LT (1998) Helicobacter pylori infection, gastric acid secretion, and infant growth. J Pediatr Gastroenterol Nutr 26: 393-397.

5. Vitale G, Barbaro F, Ianiro G, Cesario V, Gasbarrini G, Franceschi F, Gasbarrini A (2011) Nutritional aspects of Helicobacter pylori infection. Minerva Gastroenterol Dietol 57: 369-377.

6. Epplein M, Signorello LB, Zheng W, Cai Q, Hargreaves MK, Michel A, Pawlita M, Fowke JH, Correa P, Blot WJ (2011) Helicobacter pylori prevalence and circulating micronutrient levels in a low income United States Population. Cancer Prev Res (Phila) 4: 871-878.

7. Roma E, Panayiotou J, Pachoula J, Kafritsa Y, Constantinidou C, Mentis A, Syriopoulou V (2009) Intrafamilial spread of Helicobacter pylori infection in Greece. J Clin Gastroenterol 43: 711-715.

8. Holcombe C, Tsimiri S, Eldridge J, Jones DM (1993) Prevalence of antibody to Helicobacter pylori in children in northern Nigeria. Trans R Soc Trop Med Hyg 87: 19-21.

9. Etukudo OM, Ikpeme EE, Ekanem EE (2012) Seroepidemiology of Helicobacter pylori infection among children seen in a tertiary hospital in Uyo, southern Nigeria. Pan Afr Med J 12: 39.

10. Ogunlesi TA, Dedeke IOF, Kuponiyi OT (2008) Socioeconomic classification of children attending specialist paediatric centres in Ogun state, Nigeria. Niger Med Pract 54: 21-25.

11. Ukarapol N, Lertprasertsuk N, Wongsawasdi L (2004) Recurrent abdominal pain in children: the utility of upper endoscopy and histopathology. Singapore Med J 45: 121-124. 
12. Ugwuja EI, Ugwu NC (2007) Helicobacter pylori In Uninvestigated Dyspepsia In Primary Cares In Abakaliki, Nigeria. Online J Health Allied Scs 1: 4.

13. Etkin NL, Ross PJ (1982) Food as medicine and medicine as food: An adaptive framework for the interpretation of plant utilization among the Hausa of northern Nigeria. Soc Sci Med 16: 1559-1573.

14. Adeniyi BA, Anyiam FM (2004) In vitro anti-Helicobacter pylori potential of methanol extract of Allium ascalonicum Linn. (Liliaceae) leaf: susceptibility and effect on urease activity. Phytother Res 18: 358-361.

15. Smith SI, Oyedeji KS, Opere B, I walokun BA, Omonigbehin EA (2003) The effects of some Nigerian local herbs on Helicobacter pylori. Afr J Clin Exp Microbiol 4: 2935.

16. Aguemon BD, Struelens MJ, Massougbodji A, Ouendo EM (2005) Prevalence and risk-factors for Helicobacter pylori infection in urban and rural Beninese populations. Clin Microbiol Infect 11: 611-617.

17. Mohammad MA, Hussein L, Coward A, Jackson SJ (2008) Prevalence of Helicobacter pylori infection among Egyptian children: impact of social background and effect on growth. Public Health Nutr 11: 230-236.

18. Gill HH, Majumdar P, Shankaran K, Desai HG (1994) Age related prevalence of Helicobacter pylori antibodies in Indian subjects. Indian J Gastroenterol 13: 92-99.

19. Rasheed F, Ahmad T, Bilal R (2011) Frequency of Helicobacter pylori infection using 13C-UBT in asymptomatic individuals of Barakaho, Islamabad, Pakistan. J Coll Physicians Surg Pak 21: 379-381.

20. Fraser AG, Scragg R, Metcalf P, McCullough S, Yeates NJ (1996) Prevalence of Helicobacter pylori infection in different ethnic groups in New Zealand children and adults. Aust N Z J Med 26: 646-651.

21. Rothenbacher D, Bode G, Berg G, Gommel R, Gonser T, Adler G, Brenner H (1998) Prevalence and determinants of Helicobacter pylori infection in preschool children: a population-based study from Germany. Int $\mathrm{J}$ Epidemiol 27: 135-141.

22. Staat MA, Kruszon-Moran D, McQuillan GM, Kaslow RA (1996) A population-based serologic survey of Helicobacter pylori infection in children and adolescents in the United States. J Infect Dis 174: 1120-1123.

23. Ertem D, Harmanci H, Pehlivanoğlu E (2003) Helicobacter pylori infection in Turkish preschool and school children: role of socioeconomic factors and breast feeding. Turk J Pediatr 45: 114-122.

24. Rodrigues MN, Queiroz DM, Braga AB, Rocha AM, Eulailo EC, Braga LL (2006) History of breastfeeding and Helicobacter pylori infection in children: results of a community-based study from northeastern Brazil. Trans R Soc Trop Med Hyg 100: 470-475.

25. Thomas JE, Bunn JE, Kleanthous H, Monath TP, Harding M, Coward WA, Weaver LT (2004) Specific immunoglobulin A antibodies in maternal milk and delayed Helicobacter pylori colonization in Gambian infants. Clin Infect Dis 39: 11551160 .

26. Rothenbacher D, Bode G, Brenner H (2002) History of breastfeeding and Helicobacter pylori infection in pre-school children: results of a population-based study from Germany. Int J Epidemiol 31: 632-637.

27. Thomas JE, Dale A, Bunn JE, Harding M, Coward WA, Cole TJ, Weaver LT (2004) Early Helicobacter pylori colonisation: the association with growth faltering in The Gambia. Arch Dis Child 89: 1149-1154.

28. Fialho AM, Braga AB, Queiroz DM, Rodrigues MN, Herbster ID, Braga LL (2007) The association between Helicobacter pylori infection and height in children from an urban community in north-east Brazil. Ann Trop Paediatr 27: 55-61.

29. Naficy AB, Frenck RW, Abu-Elyazeed R, Kim Y, Rao MR, Savarino SJ, Wierzba TF, Hall E, Clemens JD (2000) Seroepidemiology of Helicobacter pylori infection in a population of Egyptian children. Int J Epidemiol 29: 928-932.

30. Bhuiyan TR, Qadri F, Saha A, Svennerholm AM (2009) Infection by Helicobacter pylori in Bangladeshi children from birth to two years: relation to blood group, nutritional status, and seasonality. Pediatr Infect Dis J 28: 79-85.

31. Miranda AC, Machado RS, Silva EM, Kawakami E (2010) Seroprevalence of Helicobacter pylori infection among children of low socioeconomic level in São Paulo. Sao Paulo Med J 128: 187-191.

32. Mansour MM, Al Hadidi KhM, Omar MA (2012) Helicobacter pylori and recurrent abdominal pain in children: is there any relation? Trop Gastroenterol 33: 55-61.

33. Tindberg Y, Nyrén O, Blennow M, Granström M (2005) Helicobacter pylori infection and abdominal symptoms among Swedish school children. J Pediatr Gastroenterol Nutr 41: 33-38.

34. Macarthur C, Saunders N, Feldman W, Ipp M, Winders-Lee P, Roberts S, Best L, Sherman P, Pencharz P, Veldhuyzen van Zanten SV (1999) Helicobacter pylori and childhood recurrent abdominal pain: community based case-control study. BMJ 319: 822-823.

35. Poddar U, Yachha SK (2007) Helicobacter pylori in children: an Indian perspective. Indian Pediatr 44: 761-770.

36. Macauthor C (1999) Helicobacter pylori infection and childhood reccurent abdominal pain: Lack of evidence for a cause and effect relationship. Can J Gastroenterol 13: 607610.

37. Telmesani AM (2009) Helicobacter pylori: prevalence and relationship with abdominal pain in school children in Makkah City, western Saudi Arabia. Saudi J Gastroenterol 15: 100-103.

38. Chong SK, Lou Q, Zollinger TW, Rabinowitz S, Jibaly R, Tolia V, Elitsur Y, Gold BD, Rosenberg A, Johnson A, Elkayam O, Rosenthal P, Gilger M, Li BU, Peacock JS (2003) The seroprevalence of Helicobacter pylori in a referral population of children in the United States. Am J Gastroenterol 98: 2162-2168.

39. Anyaeze CM (2003) Reducing burden of hookworm disease in the management of upper abdominal pain in the tropics. Trop Doct 33: 174-175.

\section{Corresponding author}

Dr. Idowu O. Senbanjo

Paediatric Gastroenterology, Hepatology and Nutrition Unit

Department of Paediatrics and Child Health

Lagos State University College of Medicine

PMB 21266, Ikeja, Lagos 100001, Nigeria

Phone: (+234) 08067777363

Email: senbanjo001@yahoo.com

Conflict of interests: No conflict of interests is declared. 